\title{
Some information about local rice mills and the rice (Oryza sativa L.) produced in a part of the Bida Division, Northern Nigeria
}

\author{
J. A. F. M. SLUYTERS
}

Federal Rice Research Station, Badeggi, Northern Nigeria

\begin{abstract}
Summary
A general description is given of the parboiling treatment of paddy (Oryza sativa L.) in use in a part of the Bida Division, Northern Nigeria. Some information is given on the local rice mills and the method of measurement used in trade.

Moisture percentages were determined of parboiled paddy when it is brought to the mill and of rice from the mill. The moisture percentage of the parboiled paddy and that of the rice was $16,06 \pm 0,36$. The mean percentage of broken grain in the milled rice samples was $33,09 \pm 1,78$. Information is given about losses in weight and volume which occur on drying. It reveals that measuring the rice by weight unit is more advantageous than measuring it by volume unit.
\end{abstract}

\section{Introduction}

In the investigation of factors affecting the milling quality of paddy (Oryza sativa L.) in the Federal Rice Research Station, a study was made of paddy and rice samples obtained from commercial rice mills in a part of the Bida Division of Niger Province, Northern Nigeria.

The general method of parboiling and processing in the local mills is described and some information on the trade is given. In March 1962, mills at Badeggi, Busu, Danchitagi, Doko, Jima, Katcha, Loguma, Shabo Wushi, Tsado Yaji and Yinti were visited and samples of paddy and rice collected. The moisture content and percentage of broken grain in the rice samples were measured and the data are discussed below.

\section{Local parboiling and drying method}

All the paddy brought to the rice mill is parboiled; this treatment is usually carried out by women and can, in general, be described as follows:

The paddy is soaked for 24 to 48 hours in water from wells or rivers. Sometimes the paddy is enclosed in bags. During soaking, the water is not heated. The harder the grain the longer the soaking time. It could not be ascertained whether the hardness was regarded as a characteristic of certain varieties or the result of too severe a drying process of the grain. However, a long soaking time is not very popular as it causes the final product to have a strong smell.

After soaking, the paddy is drained and boiled in fresh water. The boilers are old oil drums or kerosine tins. Sometimes the paddy is submerged during this boiling

Received for publication 13th August, 1962. 
process, sometimes the boiler is filled with water only halfway, so that part of the paddy is steamed. The time of boiling varies between half an hour to one hour. The boiling is stopped when the glumes separate at the top of the grain, so that the swollen grain appears through them.

After boiling, the paddy is usually spread in the sun for drying. Drying in the shade is not widely practised. During drying, the moisture content is tested by a combination of several methods, such as cracking the grain between the teeth and feeling it by hand. After drying, the paddy is bulked.

Several rice millers gave the information that, when the paddy is parboiled and dried the day before milling, the final product contains less broken grains than when the paddy is boiled and dried on the day of milling.

In remote villages the parboiled and dried paddy is partially hulled with mortar and pestle as this product is lighter in weight than the untreated paddy and, thus, easier to carry to the mills. In villages where a rice mill is situated, practically no partially husked paddy is brought to the mill from the village itself and the parboiled paddy is directly brought to the mill without any premilling treatment.

No information could be obtained on storage of parboiled, dried paddy. Apparently all paddy is brought to the mill directly after parboiling and drying.

\section{The local rice mills}

In the local rice mills a one-stage milling is applied, i.e. husking and polishing is done in one operation.

The mills currently in use are the Lewis Grant Mill No. 1 and a mall from McKinnon and Co. In one place a Billbrook Huller was seen. All types work on the same principle. The mills are driven by Ruston engines (1500 r.p.m.), Lister engines (12 h.p. -650 r.p.m.) or Amstrong engines (16 h.p. -1200 r.p.m., 16 h.p. -1500 r.p.m., 20 h.p. -1500 r.p.m.).

The hopper is on top of the machine. The husk and bran are taken off between a helix on a rotating, horizontal metal cylinder and a knife, which is inserted in the metal frame of the mill. The distance between the helix and the knife can be regulated according to the grain type. The discharge at the end of the helix leads into a drum containing a rotating wooden cylinder. To this are attached small leather strips, which clean and polish the rice. After this treatment the rice is discharged into a bowl.

The cleaning and polishing was exerted in two mills only. Usually this part of the machine is not in use as the leather strips wear out soon and have to be replaced every 3 months, which is too costly. The winnowing is usually done by women, outside the building. These throw the rice up in the air and the wind separates the rice from the rest of the millings. Rice mills are easy to find in the villages as they are surrounded by heaps of winnowings. These winnowings are not used for any purpose.

After the rice has been milled and winnowed, it is sold by women in the market or to a trader.

\section{Measures and trade}

None of the paddy brought to the rice mills, nor the rice sold in the market or to a trader is measured by weight. All the measures are done by volume. Two 
volumes are in current use, that is, an "ananiya" (Nupe) or "dana" (Hausa) and an "eyandan" (Nupe) or ,mudu" (Hausa). In the local mills the words ananiya and mudu are used.

An ananiya is a hemispherical bowl of $25 \mathrm{~cm}$ diameter on the top and $13 \mathrm{~cm}$ on the flat bottom, known in the hardware trade as a $10^{1 / 2}$ inch tin cash bowl. A mudu is a hemispherical bowl of $16,5 \mathrm{~cm}$ diameter on the top and $71 / 2 \mathrm{~cm}$ on the flat bottom. The ananiyas are used for measuring the paddy and the mudus for measuring the rice. Volume is measured in a heaped bowl. Slight differences occur between ananiyas and between mudus. Traders, for example, use a slightly bigger mudu when buying and a slightly smaller mudu when selling rice. These differences are localized in the rim which may be knocked out by the owner of the bowls, thus giving a better support for the heap.

The average volume of the measures and the weights they contain cannot be determined exactly. These depend on the measure itself, on the variety of rice measured and the moisture content of the grain. According to the local people, one ananiya of paddy or rice is about $3 \frac{1}{2}$ mudus of paddy or rice. The following information was collected from measuring ananiyas and mudus in the laboratory (TABLE 1).

TABLE 1. Mean volume and mean weight of two measure units of paddy and rice in local rice mills in the Bida area, Northern Nigeria

\begin{tabular}{|c|c|c|}
\hline Measure & Volume (ml) & Weight (g) \\
\hline Ananiya (paddy) & 4861 & 3093 \\
\hline Mudu (paddy) . & 1493 & 602 \\
\hline Ananiya (rice) & 5375 & 3971 \\
\hline Mudu (rice) & 1463 & 1075 \\
\hline
\end{tabular}

One ananiya of paddy gives two mudus of rice as was shown in practice, as 18 and 17 ananiyas of paddy brought to a local rice mill gave 36 and 34 mudus of rice respectively.

One bag of paddy, about 25 ananiyas, can be milled within half an hour and on one day about 20 bags can be milled. Traders sell the rice in bags of 100 mudus. No selection is made when the rice is bulked. Neither the traders nor the buyers are worried about getting mixtures of rice with high and low moisture percentages and with high and low percentages of broken grains.

During March 1962, the price of one ananiya of parboiled paddy varied between $2 / 2 \mathrm{~d}$ and $2 / 3 \mathrm{~d}$. The costs for milling one ananiya of paddy varied between $11 / 2 \mathrm{~d}$ and $2 \mathrm{~d}$ and the market price of one mudu of rice varied between $1 / 4 \mathrm{~d}$ and $1 / 6 \mathrm{~d}$.

No instances were found of traders buying parboiled paddy, having it milled and then selling the rice, although a simple calculation shows that in doing so at least a profit of $3 \mathrm{~d}$ could be made by the trader without calculating costs for transport etc. (price of one ananiya of paddy $2 / 3 \mathrm{~d}$, costs for milling $2 \mathrm{~d}$, price of two mudus of rice $2 / 8 d)$.

\section{Moisture percentage of paddy and rice}

Samples of parboiled paddy were taken out of the hopper of the rice mill and rice samples were collected from the same bulk of paddy out of the discharge. Fourteen different rice mills were visited. Occasionally only paddy or rice samples could be collected. The samples were sealed in polythene bags and brought to the laboratory 
where the moisture percentage of the cooled and ground grains was determined with a Marcone Moisture Meter. Data were recorded as averages of 4 readings. The paddy and rice samples were visually classified in A-, B- and C-grain types (GRIST, 1959). A summary of the results of each grain type is given in TABLE 2.

TABLE 2. Moisture percentages in parboiled paddy and rice samples from 14 local rice mills, Bida area, Northern Nigeria

\begin{tabular}{|c|c|c|c|c|c|c|}
\hline \multirow[t]{2}{*}{$\begin{array}{l}\text { Grain } \\
\text { type }\end{array}$} & $\mathrm{N} 1$ & $\begin{array}{l}\text { Mean moisture } \\
\text { percentage }\end{array}$ & $\begin{array}{l}\text { Coeff. of } \\
\text { variation ind. } \\
\text { observations }\end{array}$ & $\mathrm{N} 1$ & $\begin{array}{l}\text { Mean moisture } \\
\text { percentage }\end{array}$ & $\begin{array}{c}\text { Coeff. of } \\
\text { variation ind. } \\
\text { observations }\end{array}$ \\
\hline & & paddy & paddy & & rice & rice \\
\hline A & 4 & $16,75 \pm 1,38$ & 16,48 & 3 & $16,60 \pm 1,10$ & 11,51 \\
\hline$\ldots \ldots$ & 18 & $15,14 \pm 0,61$ & 16,97 & 19 & $14,78 \pm 0,61$ & 18,06 \\
\hline & 19 & $16,79 \pm 0,37$ & 9,53 & 22 & $17,09 \pm 0,35$ & 9,60 \\
\hline Total .. & 41 & $16,06 \pm 0,36$ & 14,20 & 44 & $16,06 \pm 0,36$ & 14,94 \\
\hline
\end{tabular}

$1 \mathrm{~N}=$ number of samples taken.

There were no significant differences between the mean moisture percentages of the different types of paddy. After milling, however, it shows that the B-rice type had a significantly lower mean moisture content than the $C$-rice type $(P=0,01)$. No significant differences were found between the mean moisture percentages of the paddy and the rice within each grain type.

The B-grain type had the lowest moisture percentage, the $\mathrm{C}$-grain type the highest. The decrease of the coefficient of variation of the individual observations of the moisture percentage of the milled A-grain type and the comparably low coefficient of variation of the C-grain type, both as paddy and as rice, should be noticed. There is more uniformity in the moisture percentage of the C-grain type than in the other types.

The low moisture percentage of the B-type rice is an advantage as the losses as a result of drying-up during transport will be less than those of the other types.

The mean moisture percentage of the paddy to be milled is $16 \%$. However, more uniformity is advisable especially in the A- and B-grain types. In laboratory milling tests it was found that the lowest percentage of broken grain of three rice varieties was obtained from sundried, parboiled paddy when milled at a moisture content of $16 \%$ (SLUYTERS, 1962).

\section{Percentage of broken grain in the rice}

The percentage of broken grain in the rice samples collected from commercial mills was determined with a Jerry Woodcraft Sorting Machine in the laboratory. A summary of the percentages of broken grain of each grain type is given in TABLE 3 .

The mean percentage of broken grain between the rice samples of the A-type and the B- and C-types varied considerably. The differences between the A-types and the $B$-grain types are just not yet significant $(P=0,05)$. The estimated $t$-value is 2,01 as the theoretical t-value with 46 degrees of freedom is between 2,02 and 2,01. The differences between the A-types and $C$-grain types are significant $(P=0,05)$.

This difference in mean percentage of broken grain might be an explanation for the A-grain type being rather unpopular and not widely grown in this area; it breaks up easily during milling. This was also found in laboratory milling experiments 
TABLE 3. Percentage broken grain in parboiled rice samples from 15 local rice mills, Bida area, Northern Nigeria

\begin{tabular}{lccc}
$\begin{array}{l}\text { Grain } \\
\text { type }\end{array}$ & N 1 & $\begin{array}{c}\text { Mean percentage } \\
\text { broken grain }\end{array}$ & $\begin{array}{c}\text { Coeff. of } \\
\text { variation ind. } \\
\text { observations }\end{array}$ \\
A $\ldots \ldots \ldots$ & 4 & $46,35 \pm 5,90$ & 25,46 \\
B $\ldots \ldots \ldots$ & 21 & $33,16 \pm 3,27$ & 45,11 \\
C $\ldots \ldots \ldots$ & 24 & $30,83 \pm 1,78$ & 28,22 \\
Total $\ldots \ldots$ & 49 & $33,09 \pm 1,78$ & 37,69 \\
\hline
\end{tabular}

$1 \mathrm{~N}=$ number of samples taken.

(SLUYTERS, 1962). It should, however, be taken into account that the number of observations made on the A-grain type were small in comparison with those of the B- and C-types.

The coefficient of variation of the individual observations is high, especially that of the B-grain type.

The percentage of broken grain and the coefficient of variation of the individual observations can be decreased by improving commercial practice. It was noticed that in none of the rice milling plants the mill was set according to the grain type. Also the individual paddy batches brought in usually contained mixtures of several grain types but, in general, one of these was in the majority. Sometimes the paddy was a mixture of $O$. sativa $\mathrm{L}$. and $O$. glaberrima Steud. A setting of the rice mill for each batch will reduce the percentage of broken grain. Thus, it is important for the miller to receive, and hence for the grower to produce a single grain type. Furthermore, uniformity in parboiling, drying method and moisture percentage of the parboiled paddy will result in a better milling out-turn.

It is considered that for these reasons no relationship could be found between the moisture percentage of the parboiled paddy and the percentage of broken grain after milling (SLUYTERS, 1962).

\section{Losses in volume and weight of the parboiled rice during storage and transport}

RADHAKRISHNAMURTHY et al. (1959) describes how losses in volume of wet parboiled rice during storage lead to abuses in the rice trade in India. Most of the parboiled rice obtained from the rice mill contained between 19 and $22 \%$ of moisture and when air dried in the shade, the loss in weight and volume was about $11 \%$ and $17 \%$ respectively. The bulk density of the rice rose from $0,75 \mathrm{~g} / \mathrm{ml}$ to about $0,80 \mathrm{~g} / \mathrm{ml}$.

Aithough the moisture percentage of the parboiled rice in our samples was lower than the figures given above, it was thought worthwhile to study similar effects under the Bida Division conditions.

In TABLE 4 the decrease during drying in the shade of volume and weight of $1000 \mathrm{ml}$ of 5 local rice samples is summarised. The moisture percentage was measured with a Marconi Moisture Meter (4 readings) and the volume was measured in a measuring cylinder. No attempt was made to pack the rice in the glass.

It will be seen that the loss in weight is less than the loss in volume. This is reflected in an increase of the bulk density during drying. Thus, it is more advanta- 
TABle 4. Percentage decrease in volume and weight of 5 samples of $1000 \mathrm{ml}$ of locally parboiled rice dried in the shade after milling

\begin{tabular}{|c|c|c|c|c|c|c|}
\hline \multirow[t]{2}{*}{$\begin{array}{l}\text { Grain } \\
\text { type }\end{array}$} & \multicolumn{2}{|c|}{ Moisture percentage } & \multicolumn{2}{|c|}{$\begin{array}{c}\text { Decrease in } \% \text { of } \\
1000 \mathrm{ml} \text { rice }\end{array}$} & \multicolumn{2}{|c|}{ Bulk density in $\mathrm{g} / \mathrm{ml}$} \\
\hline & from & to & $\begin{array}{l}\text { loss in } \\
\text { volume }\end{array}$ & $\begin{array}{l}\text { loss in } \\
\text { weight }\end{array}$ & from & to \\
\hline $\mathbf{B} \ldots \ldots$ & 16,9 & 10,9 & 9,0 & 6,5 & 0,770 & 0,791 \\
\hline B $\ldots$. & 14,0 & 10,7 & 4,0 & 3,7 & 0,800 & 0,802 \\
\hline C .... & 16,7 & 10,6 & 9,0 & 6,7 & 0,804 & 0,824 \\
\hline$C \ldots$ & 16,5 & 10,9 & 8,5 & 6,2 & 0,802 & 0,822 \\
\hline$C \ldots$ & 15,7 & 10,5 & 9,0 & 6,0 & 0,791 & 0,817 \\
\hline
\end{tabular}

geous to buy and sell the rice by weight than by volume (RADHAKRISHNAMURTHY et al., 1959).

In TABLE 5 the percentage decrease in volume of $500 \mathrm{~g}$ and the increase in weight of $500 \mathrm{ml}$ of 5 local rice samples are summarised.

The unit-weight volume decreases by drying-up as the unit-volume weight and the bulk density increase. From this information it appears that buying the rice per volume unit and selling it by weight unit may have its advantages; it is, however, not advisable. Measuring with two different units gives more chances to undesirable trading practices.

TABLE 5. Percentage decrease in volume of $500 \mathrm{~g}$ and increase in weight of $500 \mathrm{ml}$ of 5 local rice samples dried in the shade after milling

\begin{tabular}{|c|c|c|c|c|c|c|}
\hline \multirow{3}{*}{$\begin{array}{l}\text { Grain } \\
\text { type }\end{array}$} & \multicolumn{2}{|c|}{ Moisture percentage } & \multirow{3}{*}{$\begin{array}{c}\text { Loss in } \\
\text { volume of } \\
500 \mathrm{~g} \text { in \% }\end{array}$} & \multirow{3}{*}{$\begin{array}{c}\text { Increase in } \\
\text { weight of } \\
500 \mathrm{ml} \text { in \% }\end{array}$} & \multirow{2}{*}{\multicolumn{2}{|c|}{$\begin{array}{l}\text { Increase of bulk density } \\
\text { in } \mathrm{g} / \mathrm{ml}\end{array}$}} \\
\hline & from & to & & & & \\
\hline & & & & & from & to \\
\hline B. & $>19,0$ & 10,7 & 7,8 & 9,2 & 0,765 & 0,835 \\
\hline B . & 16,8 & 10,5 & 5,4 & 5,4 & 0,796 & 0,839 \\
\hline$C \ldots$ & 18,8 & 10,7 & 7,0 & 10,4 & 0,759 & 0,838 \\
\hline C $\ldots$ & 16,9 & 10,8 & 6,4 & 5,9 & 0,785 & 0,831 \\
\hline C $\ldots$ & 16,5 & 10,5 & 4,0 & 2,5 & 0,803 & 0,823 \\
\hline
\end{tabular}

The loss of weight in larger quantities was studied by drying one batch of $39,6 \mathrm{~kg}$ and one of $38,1 \mathrm{~kg}$ of parboiled rice in the shade (TABLE 6).

The loss by trading rice per volume unit is well known by the people. It is more or less compensated by buying the rice in a slightly bigger mudu than by selling it (see paragraph 4). Sometimes the remark was heard by miller - traders that the parboiled paddy was too wet for milling. This might have been true for the milling as such, as it would give a higher percentage of broken grain. But the loss as a result of drying-up during storage and transport would also have been considerable.

It has been shown that selling the rice per weight is more advantageous than selling it per volume. Losses by drying-up can further be decreased when the rice is bought at a fixed moisture percentage (RADHAKRISHNAMURTHY et al., 1959). 
SOME INFORMATION ABOUT LOCAL RICE MILLS AND RICE IN BIDA DIVISION (NIGERIA)

TABLE 6. Percentage decrease in weight of two batches of parboiled rice, dried in the shade after milling

\begin{tabular}{|c|c|c|c|}
\hline \multicolumn{2}{|c|}{ 1st batch $(\overline{39,5} \mathrm{~kg})$} & \multicolumn{2}{|c|}{ 2nd batch $(38,1 \mathrm{~kg})$} \\
\hline $\begin{array}{l}\text { Moisture } \\
\text { content }\end{array}$ & $\begin{array}{l}\text { Decrease in } \\
\text { weight in \% }\end{array}$ & $\begin{array}{l}\text { Moisture } \\
\text { content }\end{array}$ & $\begin{array}{l}\text { Decrease in } \\
\text { weight in \% }\end{array}$ \\
\hline 19,3 & - & 17,3 & - \\
\hline 17,7 & 1,5 & 16,2 & 3,1 \\
\hline 16,6 & 2,3 & 15,0 & 3,7 \\
\hline 15,2 & 4,5 & 14,6 & 4,2 \\
\hline 14,2 & 5,6 & 13,3 & 6,0 \\
\hline 13,7 & 6,8 & 12,9 & 6,0 \\
\hline \multirow{2}{*}{10,5} & 10,9 & 12,3 & 6,6 \\
\hline & & 11,8 & 8,4 \\
\hline
\end{tabular}

\section{ACKNOWLEDGEMENTS}

I am indebted to the Director of Agricultural Research for his permission to publish this paper, to Mr. M. C. Ezediokpu for his assistance during this survey and to Mr. B. D. A. BECK for reading the manuscript.

\section{I T ER A T UR E}

GRIST, D. H.

1959 Rice. London, Longmans, Green \& Co. Ltd. RADHAKRISHNAMURTHY, R.,
H. S. R. DESIKACHAR

1959 Loss in weight and volume of wet parboiled rice during and V. SubrahmaNYAN drying. Food Science. 8, $9: 315-316$.

SLUYTERS, J. A. F. M.

1962 Parboiled paddy dried in the sun. Relationship of moisture content and length of storage to the milling out-turn and percentage broken grain. Tropical Agriculture. Trin. (in press). 